\title{
Incidence of Phytophthora infestans (Mont.) de Bary on potato and tomato in Maine, 2006-2010
}

\author{
Ocen Modesto Olanya ${ }^{*}$, Robert Philip Larkin ${ }^{2}$, Charles Wayne Honeycutt ${ }^{3}$ \\ ${ }^{1}$ USDA-ARS, Eastern Regional Research Center, Wyndmoor, PA, 19038, USA \\ ${ }^{2}$ USDA-ARS, New England Plant, Soil and Water Laboratory, Orono, ME, 04469, USA \\ ${ }^{3}$ USDA-Natural Resource Conservation Service, Washington, D.C., 20250, USA
}

Received: September 10, 2014

Accepted: February 6, 2015

\begin{abstract}
Late blight, caused by Phytophthora infestans (Mont.) de Bary, is a devastating disease which is found worldwide. In Maine, United States (US), we recorded late blight on potato and tomato during the 2006-2009 cropping seasons. From 2006 to 2008, over 90\% of the diseased samples were collected in potato fields from northern and central Aroostook County in Northern Maine, US. Then, in 2009, an unprecedented influx of inoculum on infected tomato transplants shipped to retail garden centers throughout the Northeast US significantly changed the late blight infection patterns. In 2009, $43 \%$ of diseased samples obtained were from tomato, and $57 \%$ from potato, and disease was found to occur all over the state. Moran's index and spatial autocorrelation analysis of disease occurrence, geographical locations, host factors, and infection levels from previous years, were not statistically significant $(p>0.05)$. Therefore, random distributions of late blight incidences were recorded across locations and years. Nearest neighbor analysis revealed that mean spatial distances for late blight occurrence ranged from 1.51 to $71.4 \mathrm{~km}$ from 2006 to 2008, and 7.4 to $126.5 \mathrm{~km}$ in 2009. The frequency and locations of late blight outbreaks in 2009 were substantially greater than in 2006, 2007, and 2008, as affected by the influx of inoculum and movement of infected tomato seedlings as well as conducive environmental conditions. All were contributing factors for late blight occurrence in Maine. In 2010, few disease samples were collected, indicating that the influx of inoculum in 2009 did not persist to cause widespread disease in 2010. The reduction of inocula sources, fungicide protection of susceptible hosts, and the removal and destruction of infected tomato seedlings and potato cull piles or volunteer plants, can greatly reduce late blight occurrences and improve potato production. These actions should be considered as an integral part of late blight management programmes in regions where late blight commonly occurs.
\end{abstract}

Key words: disease distribution, $P$. infestans, potato, spatial dependence, tomato

Mention of trade names or commercial products in this publication is solely for the purpose of providing specific information and does not imply recommendation for endorsement by the US Department of Agriculture or the University of Maine. USDA is an equal opportunity employer.

\section{Introduction}

Potato late blight is caused by Phytophthora infestans (Mont.) de Bary and regarded as one of the most destructive plant diseases in the world (Birch and Whisson 2001; Judelson and Blanco 2005; Fry 2008). The annual costs for controlling late blight and the resulting losses to potato are approximated to be billions of dollars (Haverkort et al. 2008). The occurrence of $P$. infestans is of great significance due to foliar blight and tuber blight losses to potato production (Fry and Goodwin 1997). Significant economic losses or revenue losses of up to 210.7 million dollars are experienced by United States (US) potato growers, of which 77.1 million dollars are losses attributed to fungicide application costs alone (Guenthner et al. 1999, 2001). Similar economic losses amounting to millions of dollars may also impact tomato production as a result of late blight in the United States (Guenthmer et al. 2001).

Quantifying late blight among and within fields may enhance our ability to manage the disease. This task is complicated by the rapid progress of the disease on potato and tomato. In many cases, alternate hosts such as tomato (Lycopersicum esculentum L.), solanaceous weeds like hairy nightshade (Solanum sarrachoides Sendt.), volunteer potato plants, or potato refuse/cull piles have all been documented as significant inocula sources contributing to disease spread in potato (Erwin and Ribeiro 1996). Other mechanisms of inoculum dispersal and disease spread in potato have also been documented. Movement of $P$. infestans inocula within soil has been shown to be a contributing factor for the tuber blight phase of the disease (Fairclough et al. 1993; Mayton et al. 2007; Olanya et al. 2009b). Zoospores or sporangia have been implicated in short distance inoculum spread (Fairclough et al. 1993).

Aerial dispersal of $P$. infestans sporangia from lesions on leaves and stems of diseased potato or tomato plants is 
a major mechanism for dissemination of late blight from field to field over large areas (Zwankhuizen et al. 1998). Similarly, the dissemination of late blight through human activity accounted for the significant spread of the pathogen and diseased plants across regional and continental scales (Fry et al. 1993; Campbell 1999; Ristaino and Gumpertz 2000; Ristaino 2002).

Due to the devastating potential of $P$. infestans and the need to quickly control the potato disease (Duncan 1999), patterns of late blight spread within and among fields are not thoroughly documented. Several mechanisms of pathogen and disease spread may occur simultaneously resulting from combinations of aerial dispersal of sporangia and secondary spread, or movement of infected plant materials and alternate hosts.

Over the last several years, $P$. infestans has been reported in commercial potato fieldsin Maine. It has also been reported on tomato and potato in organic and home gardens throughout the state of Maine. In addition, the unique circumstances present in 2009, in which late blight pathogen inoculum was distributed throughout the state on infected tomato seedlings sold at garden centers, may have greatly affected the occurrence and distribution of late blight. Unlike other parts of the United States, late blight occurrence in Maine has been reported consistently every other year providing a residual inoculum reservoir. The broader context of this research is that the potato growing region of Maine is adjacent to the growing areas of the province of New Brunswick (Canada), and in close proximity to potato areas of the provinces of Quebec, Nova Scotia, and Prince Edward Island (Canada). The state of Maine produces seed potatoes that are shipped throughout the United States and to other countries. Changes in pathogen populations, cultural or management practices in Maine can therefore impact potato production elsewhere.

The objectives of this study were to: (1) assess the occurrence and geographical distribution of late blight on potato and tomato in 2006 through 2010, and (2) characterise the seasonal spread of potato late blight in relation to cultivar variation and cropping years. Details of the 2009 late blight pandemic in the eastern United States, as well as a discussion of its causes and results have been previously published (Fry et al. 2013).

\section{Materials and Methods}

\section{Distribution of $P$. infestans in Maine}

Samples of diseased potato or tomato plants provided by the University of Maine Cooperative Extension Service and collaborating growers, were used to document the occurrence and geographical location of late blight. Positive identification of $P$. infestans was based on symptoms typical of late blight and confirmed by pathogen isolation on Rye A media (Caten and Jinks 1968). Identification was followed by microscopic observations of colony morphology, sporangia and sporangiophores.

The locations and counties where diseased plants were obtained, the host or crop cultivar, and the date samples were collected were also recorded from the
2006-2010 growing seasons. Based on the collection record of diseased plants, the approximate geo-referenced field coordinates were determined.

\section{Late blight infection events}

Late blight infection events (the number of times late blight occurrence was reported on potato and tomato hosts) at various geographical locations, were recorded over time during each cropping year to document the number of field sites at a location (town) during the cropping cycle. Due to the risk of this disease devastating potato, no attempt was made to quantify late blight severity in the fields where disease was detected.

\section{Frequency of $P$. infestans on tomato and potato}

The frequency of $P$. infestans on symptomatic tomato and potato was recorded after positive isolation of the pathogen on Rye A selective medium (Caten and Jinks 1968). The Phytophthora infestans genotypes were characterized based on allozyme analysis (Goodwin et al. 1995) as well as for phenotypic characteristics such as mating types.

\section{Sensitivity of isolates of $P$. infestans to various fungicides}

The in vitro sensitivity of $P$. infestans isolates to protectant and systemic fungicides were assessed in laboratory experiments. The inhibition of $P$. infestans on Rye B medium amended with mancozeb, cymoxanil, and chlorothalonil, were investigated. Following the amendment of Rye B medium with mancozeb at $10 \mathrm{ppm}$, the pathogen isolates (00-87, 02-1, 06-29, 04-39, 99-1, and 99-33) were grown on the amended medium and the plates were incubated for 3 weeks (21 days). Similarly, the growth of isolate 06-29 (US-8 genotype) on Rye B medium amended with mancozeb, cymoxanil, and chlorothalonil at 10 and $100 \mathrm{ppm}$ in comparison to the untreated control $(0 \mathrm{ppm})$ were also investigated. Inhibition of $P$. infestans was computed based on the control treatment, and the results were compared graphically.

The fungicide effect on germination of zoospores and sporangia was also conducted on representative isolates of $P$. infestans. Germination of zoospores and sporangia of pathogen isolates 08-14 (100/111/122), 06-76 (111/122), $06-184(100 / 122)$, and $07-8(100 / 111 / 122)$ in the presence of mancozeb was investigated. The germination of both zoospores and sporangia was conducted on water agar amended with mancozeb at concentrations of 0 (control), $0.1,1$, and 2 ppm. For the germination of zoospores, sporangia harvested from Rye B medium and filtered to remove mycelia, were incubated in cold water $\left(4^{\circ} \mathrm{C}\right)$ to stimulate zoospore release from sporangia after the cold shock treatment. Zoospore germination (\%) was subsequently quantified on water agar amended with fungicides at 0 (control), $0.1,1$, and 2 ppm. The germination of sporangia (\%) was also quantified at the same fungicide concentrations as zoospores. 


\section{Statistical analysis}

Distribution of late blight occurrence was mapped separately for each year based on infection sites or locations. Spatial distances associated with late blight occurrences were computed based on nearest neighbor indices, which measures the distance between event locations using Geographical Information Systems (GIS) analysis (Nelson et al. 1994). The Z-statistics were used to determine significance of spatial distributions (Diggle 1983). The frequency of occurrence of $P$. infestans on diverse hosts (potato or tomato) and their relative occurrence on specific potato cultivars were computed for each year. Spatial autocorrelation analysis between occurrences of late blight to distances, host, and year was used to compute Moran's Index (I) by proc variogram. Data on fungicide effects, the inhibition of pathogen growth on Rye $\mathrm{B}$ medium and on the germination of sporangia and zoospores, were analysed by analysis of variance (ANOVA). Means and associated standard errors were computed and plotted graphically. All analyses were conducted using the Statistical Analysis System ver.9 (SAS Institute Inc., Cary, NC).

\section{Results}

\section{Distribution of $P$. infestans in Maine}

Late blight occurrence varied among cropping years and geographic locations in the northeast state of Maine. Based on positive disease diagnosis and pathogen isolations, the number of locations where disease occurred were [9, 4, 12 during 2006, 2007 and 2008 (Table 1) and 32 in 2009 (Table 2)]. The event locations (sites of late blight occurrence), showed that late blight occurred mainly in northern Maine (Aroostook County) in 2006, 2007, and 2008. The locations of disease occurrence exhibited departure from randomness $(p=0.0037)$ in the northern region during the 2006, 2007, and 2008 cropping years, but late blight was detected throughout Maine in 2009 (Fig. 1). Only three late blight samples, from two locations, both in coastal Maine (Waldeboro and Nobleboro) were collected in 2010, from both potato and tomato. Due to the low occurrence observed, no further analyses were conducted for that year.

The spatial distances of disease-spread computed among locations within each geographical region, were limited to approximately $95 \mathrm{~km}$ in 2006. In 2007 and 2008, the spatial distance of disease occurrence was less than $64 \mathrm{~km}$ in northern and central Aroostook county, except for a few occurrences in Penobscot county in 2006, as well as in Hancock and Oxford counties in 2008 (Tables 1 and 2). During 2009, the spatial distances of disease occurrences varied, but generally ranged from 7 to $91 \mathrm{~km}$. Two occurrences of late blight disease revealed an average spatial geographical distance of 126 and $182 \mathrm{~km}$ from the mean center of occurrences (Table 1). The Moran's Index was non-significant $(p>0.05)$ and, therefore, no time series analysis were conducted.

\section{Late blight infection events}

The first outbreak of $P$. infestans occurred on July 13, July 2 , July 16, June 25, and July 19, in 2006, 2007, 2008, 2009, and 2010, respectively. Infection events varied during the cropping season and among years. No infection events were recorded before the end of June except in 2009, where four infection events were recorded in June. The greatest number of subsequent new late blight infection events occurred during the weeks of July 15 to July 31 among the years (Fig. 2).

\section{Frequency of $P$. infestans on tomato and potato}

Except for the 2007 cropping year, P. infestans was detected on potato and tomato in all the years (Fig. 3). Disease recorded on tomato represented $4.5,5.8$, and $43 \%$ of late blight occurrences in 2006, 2008, and 2009, respectively. The frequency of $P$. infestans on potato was $96,100,94$, and $57 \%$ in 2006, 2007, 2008, and 2009, respectively (Fig. 3). Phytophthora infestans was detected on various potato cultivars. In 2006, late blight was found on cultivars FL1879, FL1533 (early maturity), Shepody, Norwiss, Reba (mid-maturity), and Russet Burbank (late maturity). In 2007, late blight was reported on FL1879 and Russet Burbank. Similar results were observed in 2008 and 2009. In 2008, late blight was recorded on cultivars Superior, Ontario, and Norwiss (mid-maturity) as well as on Russet Burbank and Golden Russet (late maturity), and on tomatoes. In 2009, disease occurrences were recorded on diverse potato cultivars such as FL1533 and Dark Red Norland (early maturity), and on Russet Burbank, Kennebec (late maturity) as well as on unknown potato cultivars, and on tomato. Additionally, P. infestans was detected on tomato seedlings (transplants) from various locations as well in several stores and garden centers that sold tomato seedlings in 2009. Late blight was also observed on some potato cultivars that were not readily identified.

Based on allozyme analysis at the glucose-6-phosphate isomerase (Gpi) locus (Goodwin et al. 1995), the predominant genotype designations of $P$. infestans were 100/111/122 (US-8 genotype) during the 2006, 2007, 2008 cropping years. The percentages of isolates with 100/111/122 genotype designations were 93,95 , and $97 \%$ in 2006, 2007, and 2008, respectively. The 100/122 genotype designation was also observed, and constituted 6 , 0 , and $3 \%$ of the isolates for the same years, respectively. Other pathogen genotype designations, such as 100/111 and 111/122 were also observed in 2006 and 2008, at very low frequencies. In 2009, the percentage of isolates that were of 100/111/122 and 100/122 genotype designations were 57 and $43 \%$, respectively. Isolates of the two genotype designations were recorded on diseased potato and tomato plants, and from various geographical locations in Maine. Overall, most of the isolates collected from the potato in northern Maine (mainly commercial fields) were the 100/111/122 (US-8) genotype, whereas most of the isolates on the tomato from central, coastal, and southern Maine were the 100/122 genotype. However, some isolates of 100/122 were found on the potato in 
Table 1. Nearest neighbor analysis of average spatial distance of late blight (Phytophthora infestans) occurrences in Maine in 2006, 2007, and 2008

\begin{tabular}{|c|c|c|c|c|}
\hline Location $^{\mathrm{a}}$ & County & Sample date & Region & $\begin{array}{l}\text { Mean spatial } \\
\text { distance }[\mathrm{km}]^{\mathrm{b}}\end{array}$ \\
\hline Fort Kent & Aroostook & $7 / 13 / 2006$ & Northern & 71.42 \\
\hline Mars Hill & Aroostook & $7 / 18 / 2006$ & Northern & 27.91 \\
\hline Bridgewater & Aroostook & $7 / 18 / 2006$ & Northern & 37.45 \\
\hline Mars Hill & Aroostook & $7 / 27 / 2006$ & Northern & 10.52 \\
\hline Washburn & Aroostook & $7 / 27 / 2006$ & Northern & 10.52 \\
\hline Easton & Aroostook & $8 / 2 / 2006$ & Northern & 14.71 \\
\hline Presque Isle & Aroostook & $8 / 3 / 2006$ & Northern & 6.36 \\
\hline Caribou & Aroostook & $8 / 3 / 2006$ & Northern & 14.24 \\
\hline Limestone & Aroostook & $8 / 8 / 2006$ & Northern & 25.62 \\
\hline Washburn & Aroostook & $8 / 8 / 2006$ & Northern & 10.52 \\
\hline Mapleton & Aroostook & $8 / 9 / 2006$ & Northern & 10.67 \\
\hline Caribou & Aroostook & $8 / 10 / 2006$ & Northern & 14.24 \\
\hline Westfield & Aroostook & $8 / 10 / 2006$ & Northern & 20.54 \\
\hline Presque Isle & Aroostook & $8 / 14 / 2006$ & Northern & 6.36 \\
\hline East Corinth & Penobscot & $7 / 18 / 2006$ & Southern Interior & 20.69 \\
\hline Leeds & Androscoggin & $7 / 30 / 2006$ & Southern Interior & 95.86 \\
\hline Corrina & Penobscot & $7 / 31 / 2006$ & Southern Interior & 5.16 \\
\hline Corinth & Penobscot & $8 / 1 / 2006$ & Southern Interior & 19.32 \\
\hline Orono & Penobscot & $8 / 18 / 2006$ & Southern Interior & 43.64 \\
\hline Littleton & Aroostook & $7 / 2 / 2007$ & Northern & 1.51 \\
\hline Houlton & Aroostook & $8 / 15 / 2007$ & Northern & 12.12 \\
\hline Littleton & Aroostook & $8 / 17 / 2007$ & Northern & 1.51 \\
\hline Presque Isle & Aroostook & $8 / 23 / 2007$ & Northern & 51.06 \\
\hline Caribou & Aroostook & $7 / 16 / 2008$ & Northern & 24.52 \\
\hline Grand Isle & Aroostook & $7 / 21 / 2008$ & Northern & 26.05 \\
\hline Washburn & Aroostook & $8 / 14 / 2008$ & Northern & 32.08 \\
\hline Westfield & Aroostook & $8 / 11 / 2008$ & Northern & 57.49 \\
\hline Fort Kent & Aroostook & $7 / 30 / 2008$ & Northern & 43.08 \\
\hline Grand Isle & Aroostook & $7 / 30 / 2008$ & Northern & 26.04 \\
\hline Van Buren & Aroostook & $7 / 30 / 2008$ & Northern & 14.81 \\
\hline Hamlim & Aroostook & $7 / 23 / 2008$ & Northern & 22.42 \\
\hline Mars Hill & Aroostook & $8 / 6 / 2008$ & Northern & 64.40 \\
\hline Easton & Aroostook & $8 / 5 / 2008$ & Northern & 50.11 \\
\hline Presque Isle & Aroostook & $8 / 5 / 2008$ & Northern & 44.11 \\
\hline Caribou & Aroostook & $8 / 21 / 2008$ & Northern & 24.52 \\
\hline
\end{tabular}

a locations where occurrences of late blight were reported in 2006, 2007, and 2008

${ }^{\mathrm{b}}$ spatial distance refers to mean distance from each location to mean center of locations of late blight occurrence in each region (of the state of Maine) based on the nearest neighbor index analysis 
Table 2. Nearest neighbor analysis of average spatial distance of late blight (Phytophthora infestans) occurrences in Maine during the 2009 cropping year

\begin{tabular}{|c|c|c|c|c|}
\hline Location $^{\mathrm{a}}$ & County & Sample date & Region & $\begin{array}{l}\text { Mean spatial } \\
\text { distance }[\mathrm{km}]^{\mathrm{b}}\end{array}$ \\
\hline Houlton & Aroostook & $6 / 25 / 2009$ & Northern & 55.74 \\
\hline Presque Isle & Aroostook & 7/7/2009 & Northern & 7.39 \\
\hline Fort Fairfield & Aroostook & $7 / 20 / 2009$ & Northern & 21.30 \\
\hline Easton & Aroostook & $7 / 31 / 2009$ & Northern & 7.15 \\
\hline Sherman & Aroostook & $7 / 31 / 2009$ & Northern & 88.94 \\
\hline Presque Isle & Aroostook & $7 / 31 / 2009$ & Northern & 7.39 \\
\hline Presque Isle & Aroostook & $8 / 5 / 2009$ & Northern & 7.39 \\
\hline Mapleton & Aroostook & $8 / 5 / 2009$ & Northern & 14.75 \\
\hline Bangor & Penobscot & $6 / 25 / 2009$ & Southern Interior & 16.93 \\
\hline Bangor & Penobscot & $7 / 12 / 2009$ & Southern Interior & 16.93 \\
\hline Orono & Penobscot & $7 / 13 / 2009$ & Southern Interior & 25.82 \\
\hline Brewer & Penobscot & $7 / 20 / 2009$ & Southern Interior & 18.29 \\
\hline Waterville & Kennebec & $7 / 14 / 2009$ & Southern Interior & 59.35 \\
\hline Sangerville & Piscataquis & $7 / 22 / 2009$ & Southern Interior & 47.44 \\
\hline Dover Foxcroft & Piscataquis & $7 / 22 / 2009$ & Southern Interior & 43.85 \\
\hline Canton & Oxford & $7 / 22 / 2009$ & Southern Interior & 11.36 \\
\hline Newport & Penobscot & $7 / 22 / 2009$ & Southern Interior & 22.55 \\
\hline Fryeburg & Oxford & $7 / 26 / 2009$ & Southern Interior & 182.30 \\
\hline Exeter & Penobscot & $7 / 26 / 2009$ & Southern Interior & 19.92 \\
\hline Albion & Kennebec & $7 / 31 / 2009$ & Southern Interior & 48.58 \\
\hline Orono & Penobscot & $7 / 31 / 2009$ & Southern Interior & 25.83 \\
\hline Palmyra & Somerset & $8 / 5 / 2009$ & Southern Interior & 29.30 \\
\hline Sebec & Piscataquis & $8 / 5 / 2009$ & Southern Interior & 50.44 \\
\hline Lewiston & Andoscoggin & $8 / 5 / 2009$ & Southern Interior & 126.54 \\
\hline Ellsworth & Hancock & 7/7/2009 & Coastal & 115.99 \\
\hline Dresden & Lincoln & $7 / 12 / 2009$ & Coastal & 4.23 \\
\hline Dresden & Lincoln & $7 / 14 / 2009$ & Coastal & 4.23 \\
\hline Bowdoinham & Sagadahoc & $7 / 14 / 2009$ & Coastal & 16.07 \\
\hline Warren & Knox & $7 / 20 / 2009$ & Coastal & 38.47 \\
\hline Warren & Knox & $7 / 22 / 2009$ & Coastal & 38.47 \\
\hline Lisbon Falls & Androscoggin & $7 / 26 / 2009$ & Coastal & 28.84 \\
\hline Dayton & York & $7 / 31 / 2009$ & Coastal & 91.48 \\
\hline
\end{tabular}

${ }^{a}$ locations where occurrences of late blight were reported in 2009

${ }^{\mathrm{b}}$ spatial distance refers to mean distances from each location to mean center of locations of late blight occurrence in each region (of the state of Maine) based on the nearest neighbor index analysis 

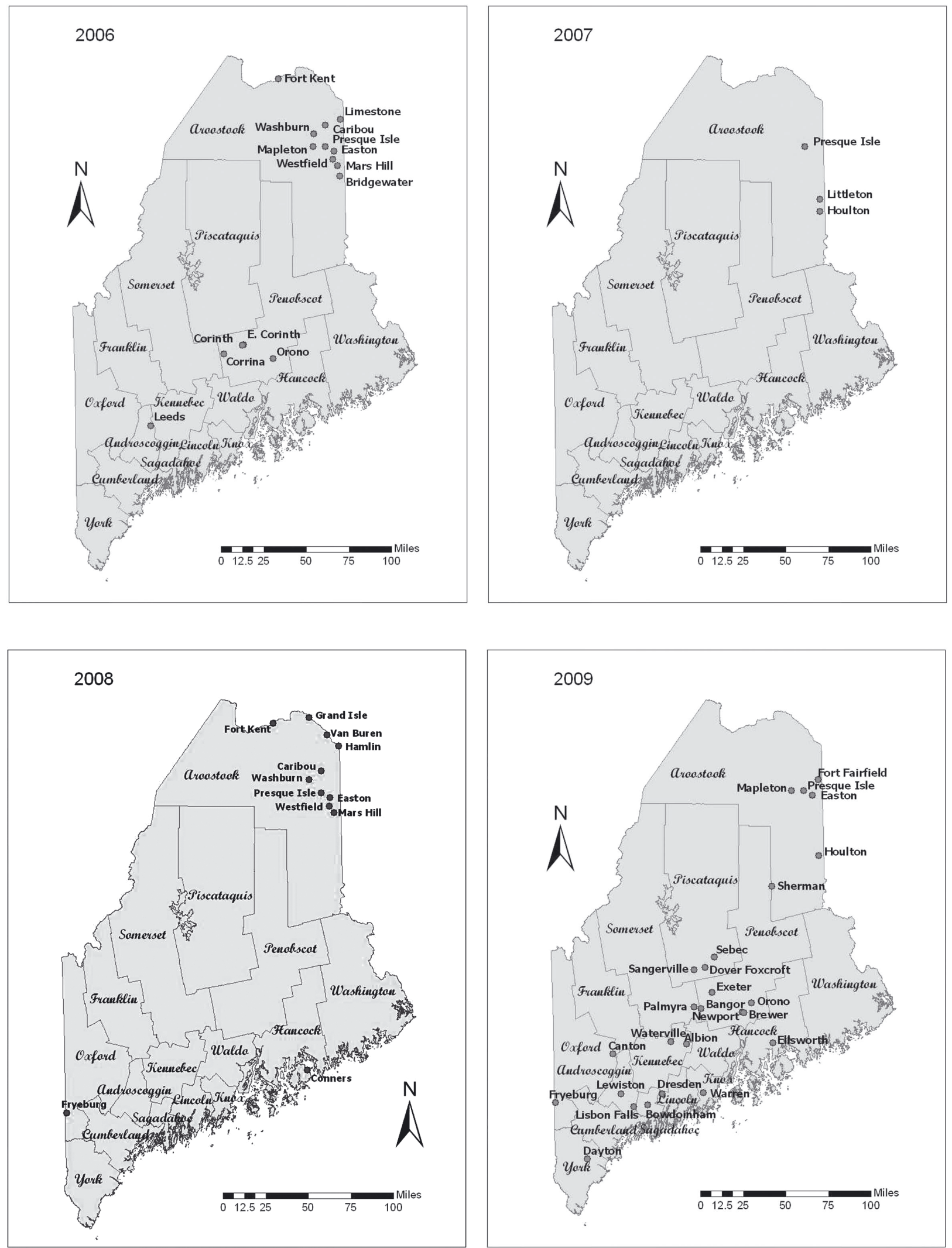

Fig. 1. Distribution of late blight on tomato and potato plants (late blight events) in fields at various geographic locations in Maine. The county names in the State of Maine (US) are in italics

northern Maine, and some isolates of 100/111/122 were also found on the tomato in coastal Maine. The pathogen mating type was A2 for all isolates collected in 20062009. Isolates of the 100/122 genotype collected in 2009 were later analysed by others using the RG57 DNA fingerprint probe (Goodwin et al. 1992) and determined to be of the new genotype designated US-22 (Hu et al. 2012; Fry et al. 2013). 


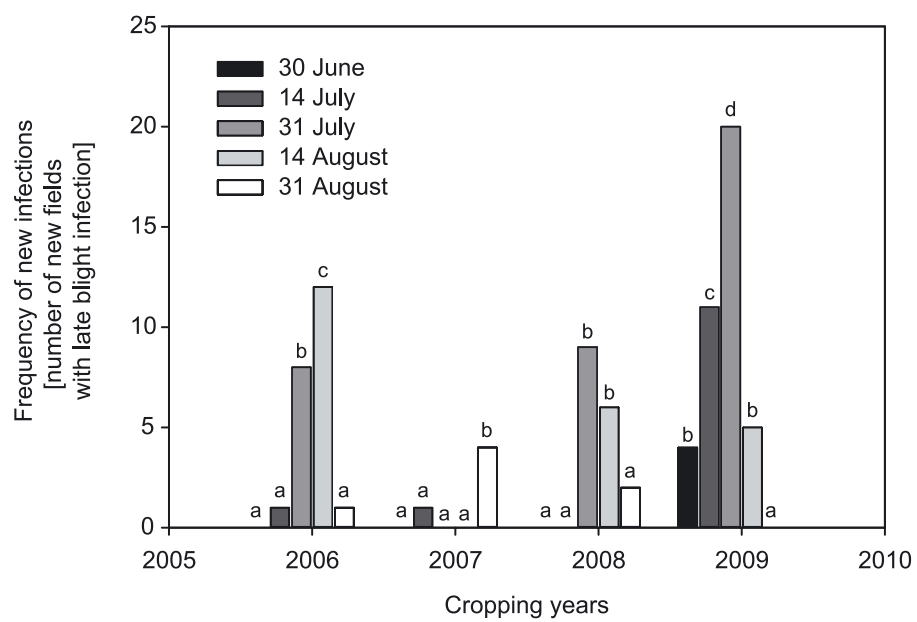

Fig. 2. Phytophthora infestans infection of potato and tomato hosts from 2006 to 2009 cropping years in Maine. Data refers to numbers of new infections recorded on both hosts within each assessment period. The bars with the same letters within each year indicate that the frequency of new infections at different assessment periods are not significantly different $(p>0.05)$

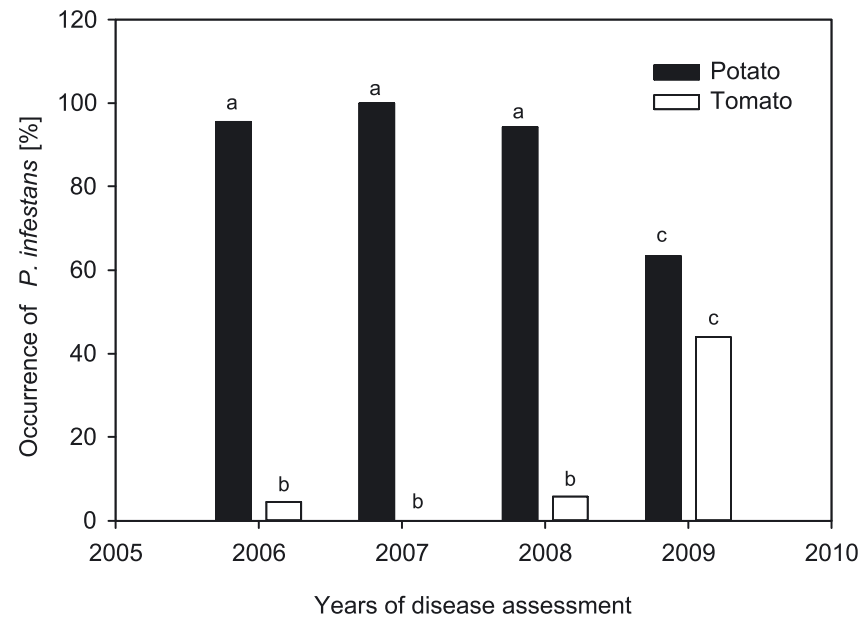

Fig. 3. Occurrences of Phytophthora infestans on potato and tomato from 2006 to 2009 cropping years. Data refer to the percentage of hosts infected with late blight during each year. Bars with different letters indicate significant differences $(p<0.05)$ in late blight occurrence between the two hosts within each year

\section{Sensitivity of isolates of $P$. infestans to various fungicides}

The inhibition of in vitro growth of $P$. infestans generally varied among isolates and ranged from $10-50 \%$ at day 4 to $62-80 \%$ at 21 days after incubation (Fig. 4 ). At twentyone days of incubation, the greatest inhibition was recorded on isolate 99-1 (86/100, US-1) and the lowest inhibition was detected on 99-33 (100/111/122, US-8). When comparisons were made among mancozeb, cymoxanil, and chlorothalonil, at $100 \mathrm{ppm}$, the lowest inhibition of growth was detected on cymoxanil (Fig. 4).

The average germination of zoospores varied among pathogen isolates and ranged from $40-80 \%$ on the unamended medium (Fig. 5). On medium amended with mancozeb, at 1 and 2 ppm, complete inhibition of zoospore germination was detected and there was no significant difference in the inhibitory effect of fungicide concentrations on zoospore germination. Germination of sporangia in medium amended with fungicide such as mancozeb differed slightly among the tested patho- gen isolates. Low germination of sporangia was detected across $P$. infestans isolates and ranged from $20-30 \%$ at $18^{\circ} \mathrm{C}$ (Fig. 5).

\section{Discussion}

The occurrences of late blight and $P$. infestans were recorded from the 2006 to 2010 cropping seasons in Maine. Late blight has been previously reported in potato-growing areas in Maine throughout the years (Groves 2002; Johnson 2005; Olanya et al. 2005) and in other potato growing regions with favorable environmental conditions for disease development (Fry and Goodwin 1997). Differences in the number of disease occurrences in various geographical locations from 2006 to 2009 suggest that variation of $P$. infestans inocula among locations and years are important contributing factors. Variations in pathogen spread and the effectiveness of disease-control measures may also have contributed to the differences observed in late blight occurrences among locations and years. The lowest number of late blight infections was observed in 2007, 

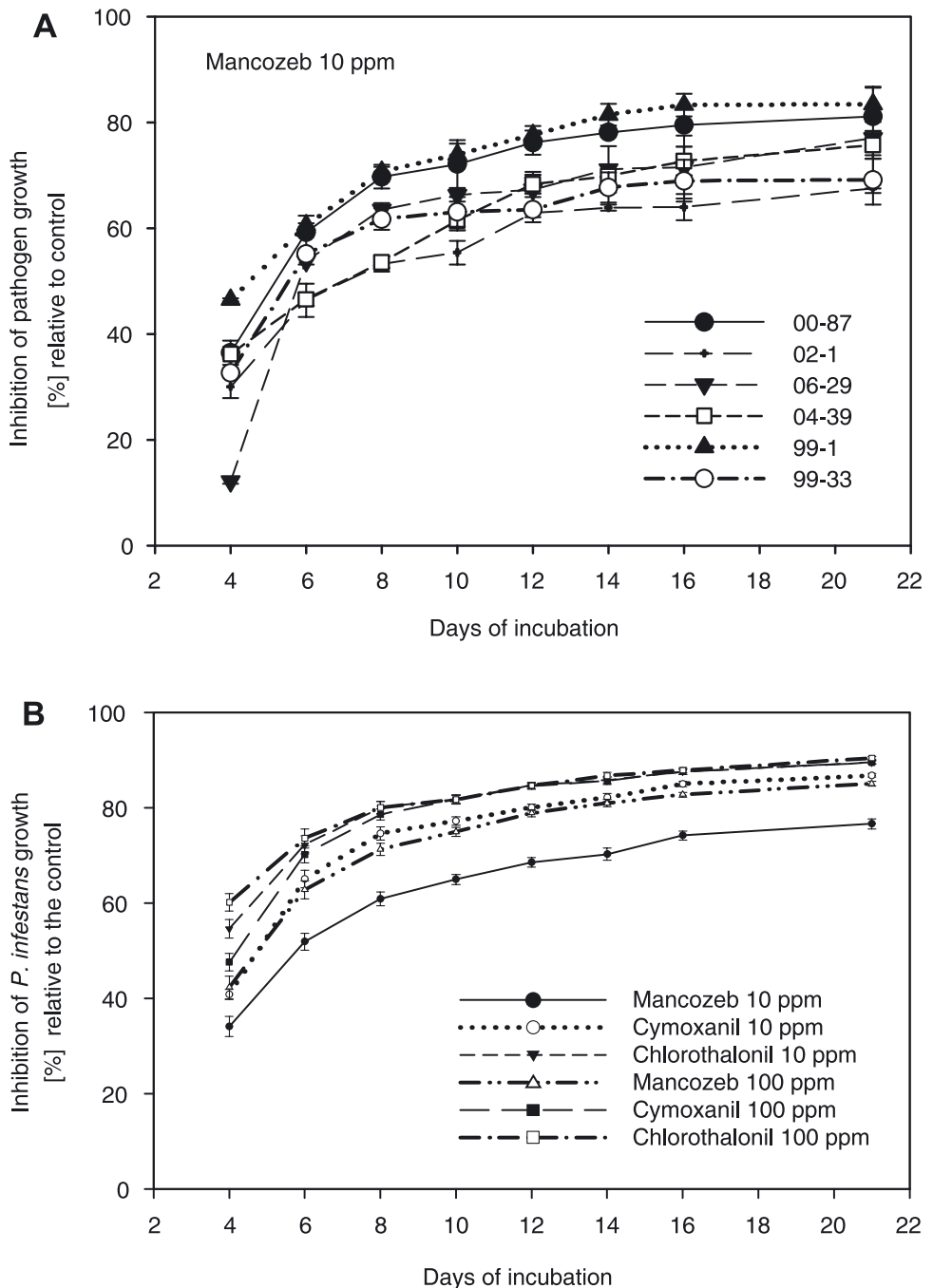

Fig. 4. Growth of Phytophthora infestans isolates on Rye B media $\left(18^{\circ} \mathrm{C}\right)$ amended with mancozeb at $10 \mathrm{ppm}$. Isolates $00-87,02-1$, and 99-1 (US-1) represent genotype designations 100/100, 100/122, and 86/100, respectively. Isolates 06-29 and 04-39 are 100/111/122 (US-8) based on allozyme analysis. The reference isolates are 99-1 (86/100, US-1) and 99-33 (100/111/122, US-8). The inhibition of growth of 06-29 on Rye B medium amended with mancozeb, cymoxanil, and chlorothalonil fungicides at 10 and $100 \mathrm{ppm}$ were also determined
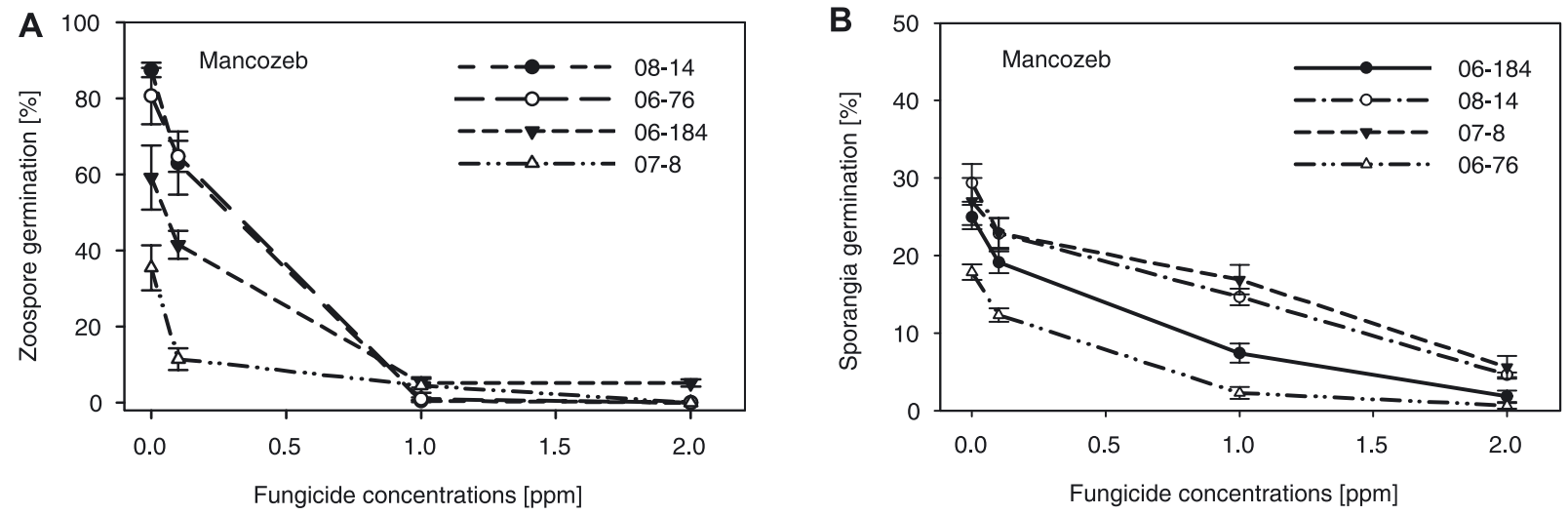

Fig. 5. Effects of fungicide (mancozeb) application on the germination of sporangia and zoospores of Phytophthora infestans isolates. The germinations of zoospores and sporangia were assessed on water agar amended with mancozeb at 0 (the control), 0.1, 1, and 2 ppm. The isolates and their genotype designations were: 06-76 (111/122), 06-184 (100/122), 07-8, and 08-14 (100/111/122) 
suggesting that the presence of low levels of inocula, less suitable environmental conditions, effective disease control, or a combination of these factors were active. The greatest number of late blight occurrences observed in 2009 , implies that there were greater inocula of $P$. infestans in the various growing regions, the presence of suitable environmental conditions for late blight development, and the possibility that the pathogen spread to various geographical regions, or a combination of these factors.

Variation in the spatial distances of late blight occurrences at diverse locations and years, suggests that $P$. infestans can spread across different spatial scales (Fry et al. 1993; Ristaino and Gumpertz 2000). In 2006, 2007, and 2008, the spatial distances among locations where late blight occurred were limited to $80 \mathrm{~km}$. In 2009, spatial distances based on nearest neighbor distance analysis were about $40 \mathrm{~km}$, although disease occurrences were widespread throughout the state of Maine and the entire northeastern United States. This implies that sources of inocula or mechanisms of disease-spread were more diverse during the 2009 cropping season compared to the other cropping years. In 2007 and 2008, late blight occurrences or spread may have been constrained by limited inocula sources, effective disease control, or by a less than optimum environment. In 2009, the unprecedented influx of inoculum and spread of disease on late blight-infected tomato seedling transplants sold at retail stores and garden centers throughout the northeast, drastically affected late blight patterns. This widespread inoculum source combined with very favorable environmental conditions for late blight development resulted in a very early disease development, widespread occurrence, and repeated outbreaks on both tomato and potato throughout the state.

Late blight was detected in June 2009. But by the time the extent of infection and the widespread distribution of the diseased transplants was determined, the disease had already been spread throughout the northeastern US (Fry et al. 2013). Effects of the 2009 late blight pandemic were most strongly felt by home gardeners and organic growers. Many people with backyard tomato plants, and home and organic potato fields found their plants destroyed as they were not prepared and able to deal with the consequences of this devastating disease (Fry et al. 2013). Thus, most of the isolates of $P$. infestans recovered from tomatoes and potatoes from central and southern parts of the state, were the same genotype and likely derived directly from the infected tomato transplants. However, this influx of inoculum, in general, had less impact on the late blight observed in commercial potato fields in northern Maine, which tended to be the same type (100/111/122, US-8) that has been predominantly observed in recent years in the state. Damage was also much less severe in commercial potato fields. This was due to the routine spraying of fungicides to control late blight and the ability to quickly respond to initial reports of disease outbreaks. Thus, the higher frequencies and occurrences of late blight in northern Maine in 2009, were probably more related to the conducive environmental conditions than the inoculum influx from tomato seedlings. However, the tomato strain of the pathogen was also observed on po- tato in northern Maine, and this strain also affected late blight in the north. Likewise, the potato isolate (US-8) was also observed in other parts of the state as well, although to a much lesser extent than the tomato isolate. These findings indicate that both pathogen genotypes were distributed statewide and affected the late blight epidemic. Experimental evidence for aerial dispersal of $P$. infestans on potato has shown that dispersal from field to field occurs within relatively limited distances (Ristaino and Gumpertz 2000). However, long distance spread has previously been attributed to human activity involving movement or transportation of diseased plant materials such as infected seed and transplants (Campbell 1999; Ristaino and Gumpertz 2000). In this case, the presence and distribution of diseased tomato seedlings across the state of Maine was a notable consequence of human activity and widespread infection from diverse inocula sources.

Infection of tomato by $P$. infestans has been previously documented in Maine and many other potato growing regions of the US and Canada (Vartanian and Endo 1985; Platt 1999; Olanya et al. 2009a). Overwintering and survival of $P$. infestans on tomato has also been documented in a California field (Vartanian and Endo 1985). Infection rates and sporangia production on diseased tomato plants by $P$. infestans were shown to be similar to that on potato under controlled environmental conditions (Olanya et al. 2009a). This suggests that diverse genotypes of $P$. infestans can infect potato or tomato. Tomato cultivation and production has been increasing in the state of Maine recently, due to home gardens and greenhouse/glasshouse operations. Because late blight can be disseminated via diseased tomato plants (seedling transplants), fruits, and seeds, precautions should be exercised in the production of tomato, transportation of seedlings as well as the management of late blight at local, state, and regional levels. Following the late blight epidemic in 2009, late blight in Maine in 2010 was limited, with only a few reported outbreaks which were very localised in nature. This indicates that the large influx of inoculum on tomato seedlings, and widespread occurrence of late blight in 2009, did not have large-scale lasting effects on late blight inoculum or the frequency and distribution of late blight in the following year. This may be due primarily to unfavorable environmental conditions in 2010, but also indicates that, for the most part, inoculum from 2009 did not survive through the winter to cause widespread disease in 2010.

With regard to fungicide sensitivity, differences in the reduction of the in vitro growth of pathogen isolates on medium amended with cymoxanil, chlorothalonil, and mancozeb fungicides, suggest that isolates differ in their sensitivities to fungicides. The result may be different levels of efficacy. Similarly, germination of zoospores and sporangia also varied among fungicides. Although protectant (chlorothalonil and mancozeb) and systemic (cymoxanil) fungicides may differ in their mode of activity, their efficacy on pathogen isolates based on in vitro experiments were similar. The low germination of zoospores and sporangia exposed to mancozeb, suggests that low concentrations of fungicidal compounds are needed for effective inhibition of the germination of zoospores and 
sporangia. Various authors have previously documented the inhibition of the germination of sporangia and zoospores in response to fungicide compounds. Although US-22 (100/122 designation) was the dominant lineage in 2009 in the United States, in Maine this lineage and US-8 (100/111/122) were both recorded. The sensitivity of US-22 lineage to mefenoxam suggests that inoculum derived from this genotype can be easily destroyed by the fungicide. However, the predominate fungicides applied in potato fields in Maine consist of mancozeb and chlorothalonil (protectant), alternated with cymoxanil and occasionally mefenoxam (systemic) as well as some others. Therefore, it is possible that residual inoculum for lineage US-22 (100/122) could have persisted in subsequent years.

We conclude that occurrence and distribution of $P$. in festans on potato and tomato were impacted by various sources of inocula, dispersal mechanisms and patterns, and their interaction with crop and disease management practices or environmental factors. It appears that a combination of pathogen dissemination mechanisms and the dispersal of sporangia may have occurred simultaneously to account for disease spread. Due to favorable temperature, relative humidity and rainfall conditions during the potato cropping seasons in Maine, late blight spread readily occurred. Elimination or minimising sources of inocula, followed by prompt control measures would reduce the likelihood of late blight infections. Similarly, limiting the movement of potential Solanaceous hosts as well as tomato seedlings infected by late blight within a growing season, and following prudent cultural and chemical control strategies should also reduce the likelihood of infection or disease potential on potato.

\section{Acknowledgments}

We thank the University of Maine Cooperative Extension (Drs. Steve Johnson, James Dwyer, and James Dill) and collaborating growers for providing the diseased plant samples. The technical assistance of Ethel Champaco and Peggy Pinette are greatly appreciated.

\section{References}

Birch P.R., Whisson S.C. 2001. Phytophthora infestans enters the genomic era. Molecular Plant Pathology 2 (5): 257-263.

Campbell C.L. 1999. The importance of dispersal mechanisms in the epidemiology of Phytophthora blights and downy mildews on crop plants. Ecosystem Health 5 (3): 146-157.

Caten C.E, Jinks J.L. 1968. Spontaneous variation of single isolates of Phytophthora infestans. I. Cultural variation. Canadian Journal of Botany 46 (4): 329-348.

Christian J.P., Nelson L.B., Lembo A.J., Wilkins J.L., Fick G.W. 2008. Mapping potential foodsheds in New York State: A spatial model for evaluating the capacity to localize food production. Renevable Agriculture and Food Systems 24 (1): 72-84.

Diggle P.J. 1983. Statistical Analysis of Spatial Point Patterns. 2nd ed. Academic Press, London, Oxford University Press, UK, $159 \mathrm{pp}$.

Duncan J.M. 1999. Phytophthora - an abiding threat to our crops. Microbiology Today 26: 114-116.
Erwin D.C., Ribeiro O.K. 1996. Phytophthora Diseases Worldwide. APS Press, St. Paul, MN, USA, 592 pp.

Fairclough R., Bain R.A., Holmes S.J. 1993. The effects of soil moisture content on the infection of daughter tubers by Phytophthora infestans and subsequent disease transmission. Proceedings of Crop Protection in Northern Britain, Dundee. Society for Crop Protection in Northern Britain, p. 325-330.

Fry W.E. 2008. Phytophthora infestans: the plant (and $R$ gene) destroyer. Molecular Plant Pathology 9 (3): 385-402.

Fry W.E., Goodwin S.B., Dyer A.T., Matuszak J.M., Drenth A., Tooley P.W., Sujkowski L.S., Koh Y.J., Cohen B.A., Spielman L.J., Deahl K.L., Inglis D.A., Sandlan K.P. 1993. Historical and recent migrations of Phytophthora infestans: chronology, pathways, and implications. Plant Disease 77: 653-661.

Fry W.E., Goodwin S.B. 1997. Resurgence of the Irish potato famine fungus. Bioscience 47 (6): 363-371.

Fry W.E., McGrath M.T., Seaman A., Ziter T.A., McLeod A., Danies G., Small I.M., Myers K., Everts K., Gevens A.J., Gugino B.K., Johnson S.B., Judelson H., Ristaino J., Roberts P., Secor G., Seebold K., Snover-Clift K., Wyenandt A., Grunwald N., Smart C. 2013. The 2009 late blight pandemic in the eastern United States - causes and results. Plant Disease 97: 296-306.

Goodwin S.B., Drenth A., Fry W.E. 1992. Cloning and genetic analyses of two highly polymorhphic, moderately repetitive nuclear DNAs from Phytophthora infestans. Current Genetics 22 (2): 107-115.

Goodwin S.B., Drenth A., Fry W.E. 1995. Use of cellulose acetate electrophoresisfor rapid identification of allozymes of Phytophthora infestans. Plant Disease 79: 1181-1185.

Groves C.L. 2002. Characterization of Phytophthora infestans from Maine during 1999 to 2000. American Journal of Potato Research 79 (5): 325-333.

Guenthner J.F., Michael K.C., Nolte P. 2001. The economic impact of potato late blight on US growers. Potato Research 44 (2): 121-125.

Guenthner J.F., Weise M.V., Pavlista A.D., Sieczka J.B., Wyman J. 1999. Assessment of pesticide use in US potato industry. American Journal of Potato Research 76 (1): 25-29.

Haverkort A.J., Boonekamp P.M., Hutten R., Jacobsen E., Lotz L.A.P., Kessel G.J.T., Visser R.G.F., van der Vossen E.A.G. 2008. Societal costs of late blight in potato and prospects of durable resistance through cisgenic modification. Potato Research 51 (1): 47-57.

Hu C.-H., Perez F., Donohoo R., McLeod A., Myers K., Ivors K., Secor G., Roberts P., Deahl K., Fry W.E., Ristaino J.B. 2012. Recent genotypes of Phytophthora infestans in eastern USA reveal clonal populations and reappearance of mefenoxam sensitivity. Plant Disease 96 (9): 1323-1330.

Johnson S.B. 2005. Late blight prediction in Maine. The University of Maine, Cooperative Extension Service, Bulletin 2418, $4 \mathrm{pp}$.

Judelson H.S., Blanco F.A. 2005. The spores of Phytophthora: Weapons of the plant destroyer. Nature Review Microbiology 3 (1): 47-58.

Mayton H., Myers K., Fry W.E. 2007. Potato late blight in tubers - the role of foliar phosphonate applications in suppressing pre-harvest tuber infections. Crop Protection 27 (6): 943-950. 
Nelson M.R., Felix-Gastelum R., Orum T.V., Stowell L.J., Myers D.E. 1994. Geographical information systems and geostatistics in the design and validation ofregional plant virus management programs. Phytopathology 84: 898-905.

Olanya O.M., Lambert D.H., Plant A.B. 2005. Occurrence and cross-infection of Phytophthora infestans on hairy night shade (Solanum sarrachoides) and potato (Solanum tuberosum) in Maine. Canadian Journal of Plant Pathology 27 (3): 458-460.

Olanya O.M., Plant A.B., Larkin R.P., Honeycutt C.W. 2009a. Infection potential of hairy nightshade (Solanum sarrachoides) by Phytophthora infestans and late blight implications of the alternate host. Journal of Phytopathology 157: 427-437.

Olanya O.M., Ojiambo P.S., Nyankanga R.O., Honeycutt C.W., Kirk W.W. 2009b. Recent developments in managing tuber blight of potato (Solanum tuberosum) caused by Phytophthora infestans. Canadian Journal of Plant Pathology 31 (3): 280-289.

Platt H.W. 1999. Response of solanaceous cultivated plants and weed species toinoculation with A1 or A2 mating type strains of Phytophthora infestans. Canadian Journal of Plant Pathology 21 (3): 301-307.

Ristaino J.B., Gumpertz M.L. 2000. New frontiers in the study of dispersal and spatial analysis of epidemics caused by species in the genus Phytophthora. Annual Review of Phytopathology 38: 541-576.

Ristaino J.B. 2002. Tracking historic migrations of the Irish potato famine pathogen, Phytophthora infestans. Microbes and Infection 4 (13): 1369-1377.

Vartanian V.G., Endo R.M. 1985. Overwintering hosts, compatibility types, andraces of Phytophthora infestans on tomato in southern California. Plant Disease 69 (6): 516-519.

Zwankhuizen M.J., Govers F., Zadoks J.C. 1998. Development of potato late blight epidemics: disease foci, disease gradients, and infection sources. Phytopathology 88 (8): 754-763.

Zwankhuizen M.J., Govers F., Zadoks J.C. 2000. Inoculum sources and genotypic diversity of Phytophthora infestans in southern Flevoland, the Netherlands. European Journal of Plant Pathology 106 (7): 667-680. 